
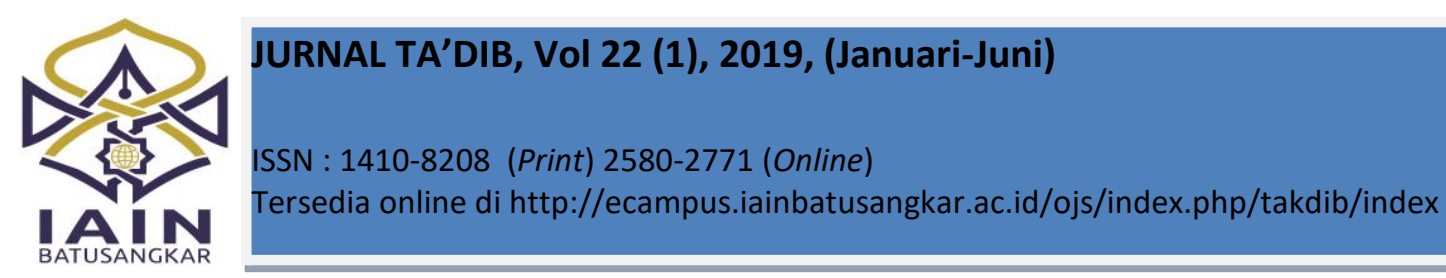

\title{
Analisis Kemampuan Representasi Matematis Siswa dalam Menyelesaikan Soal Pemecahan Masalah Matematika
}

\author{
Ummul Huda*) \\ Institut Agama Islam Negeri Batusangkar, \\ Sumatera Barat, Indonesia \\ Email:ummulhuda@iainbatusangkar.ac.id
}

\section{Edwin Musdi}

Universitas Negeri Padang, Sumatera Barat, Indonesia

Email: win_musdi@yahoo.co.id

\section{Nola Nari}

Institut Agama Islam Negeri Batusangkar, Sumatera Barat, Indonesia

Email: nolanari@iainbatusangkar.ac.id

*) Corresponding Author

\begin{abstract}
Abstrak: This research is motivated by the low mathematical representation ability of students in solving mathematical problem solving questions based on TIMSS data and facts in the field. The study aims to analyze the mathematical representation ability of MTsN Batusangkar students visually, verbally and symbolically in solving mathematical problem solving problems. This field research uses descriptive method. The instrument used is a description question and interview guide. Quantitative data based on test results were analyzed to determine the predicate of mathematical representation ability, while Miles and Huberman model wwas used to analyze qualitative data from interviews. The results show that students' mathematical visual and symbolic abilities are satisfactory, while verbal mathematical representations are less satisfactory.
\end{abstract}

Kata Kunci: Analysis, Mathematical representation ability, Mathematical problem solving questions

\section{$\mathrm{K}$} siswa atas ketetapan NCTM. Kemampuan representasi menjadi pendukung bagi siswa dalam memahami konsep-konsep matematika beserta kaitannya; mengkomunikasikan ide matematika siswa; memahami koneksi antar konsep; dan penerapannya dalam kehidupan sehari-hari melalui pemodelan (Hudiono dalam Aryanti, Zubaidah, \& Nursangaji, 2013). Hal ini menunjukkan bahwa kemampuan representasi matematis menjadi penunjang bagi kemampuan matematis lainnya seperti kemampuan pemahaman konsep, koneksi, komunikasi dan pemecahan masalah.

Jones dan Knuth dalam Sabirin (2014) mengatakan bahwa representasi merupakan cara lain dalam menyajikan kondisi soal, misalnya dalam bentuk objek, kata-kata, gambar atau simbol matematika. Selanjutnya, NCTM dalam Dahlan \& Juandi
(2011) menuturkan bahwa representasi adalah penyajian suatu masalah dalam bentuk yang berbeda semisal gambar, simbol, kata atau kalimat. Representasi juga berguna dalam menguraikan masalah verbal agar lebih sederhana. Uraian di atas mengandung beberapa makna representasi, diantaranya: a) representasi melibatkan penguraian masalah atau gagasan dalam bentuk yang berbeda, b) mengubah diagram ke bentuk simbol atau istilah-istilah, dan c) dapat digunakan dalam menganalisis dan menerjemahkan masalah sehingga maknanya lebih jelas.

Berdasarkan beberapa uraian di atas, disimpulkan bahwa representasi merupakan tafsiran dari pemahaman siswa berupa ideide yang terkontruksi di dalam pikiran terhadap suatu masalah yang dikomunikasikan dalam bentuk fisik berupa istilah-istilah, gambar, tulisan, benda konkrit atau simbol untuk memudahkan penemuan solusi dari suatu permasalahan. Sedangkan kemampuan representasi matematis ialah 
kemahiran siswa dalam mencetuskan gagasan-gagasan matematika (arti, penjelasan, persoalan, dan lain-lain) untuk menyampaikan hasil pekerjaannya dengan cara-cara khusus sebagai bentuk dari hasil pemikiran siswa untuk mencari solusi dari masalah yang sedang dihadapinya.

Lesh, Post dan Behr dalam Kartini (2009) mengelompokkan representasi matematis menjadi lima bagian, yaitu representasi objek dunia nyata, representasi konkret, representasi bentuk aritmatika, representasi verbal atau bahasa lisan serta representasi gambar atau grafik. Dari kelima bagian tersebut tiga kelompok terakhir lebih abstrak dan merupakan tingkat representasi yang lebih tinggi dalam menyelesaikan masalah matematika. Selanjutnya, ketiga jenis representasi itulah yang akan diamati dalam penelitian ini, antara lain representasi visual (gambar, grafik, diagram atau tabel), representasi simbolik (notasi matematis, bentuk aljabar) dan representasi verbal (teks tertulis).

Berdasarkan uraian tersebut, menurut Ansari dalam Fauzan (2013) indikator beserta bentuk-bentuk operasional yang digunakan dalam menilai kemampuan representasi matematis siswa secara lengkap terlihat dalam tabel berikut:

\section{Tabel 1}

Bentuk Operasional Kemampuan Representasi Matematis

\begin{tabular}{|c|c|c|}
\hline No & Representasi & Bentuk Operasional \\
\hline \multirow[t]{2}{*}{1} & $\begin{array}{l}\text { Visual berupa } \\
\text { a. Grafik, diagram } \\
\text { atau tabel }\end{array}$ & \begin{tabular}{ll} 
- & \multicolumn{2}{l}{ Menyajikan kembali data atau } \\
informasi ke dalam grafik, \\
diagram atau tabel \\
- $\begin{array}{l}\text { Memanfaatkan representasi } \\
\text { visual untuk memecahkan } \\
\text { masalah }\end{array}$ \\
\end{tabular} \\
\hline & b. Gambar & 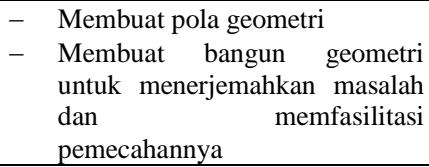 \\
\hline 2 & $\begin{array}{l}\text { Simbolik } \\
\text { (persamaan atau } \\
\text { ekspresi } \\
\text { matematis) }\end{array}$ & 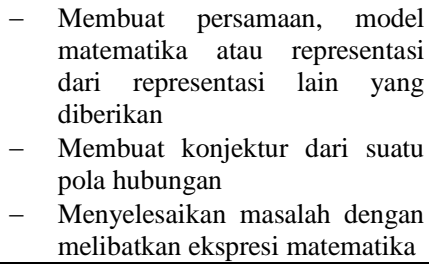 \\
\hline 3 & $\begin{array}{l}\text { Verbal (kata-kata } \\
\text { atau teks tertulis) }\end{array}$ & $\begin{array}{ll}\text { - } & \text { Membuat situasi masalah } \\
\text { berdasarkan data atau } & \\
\text { representasi yang diberikan } \\
\text { - } & \begin{array}{l}\text { Menuliskan interpretasi dari } \\
\text { suatu representasi }\end{array} \\
\text { - } & \text { Menuliskan langkah-langkah }\end{array}$ \\
\hline
\end{tabular}

\begin{tabular}{|c|c|c|}
\hline No & Representasi & Bentuk Operasional \\
\hline & & $\begin{array}{l}\text { pemecahan maslah matematika } \\
\text { secara tertulis } \\
\text { - } \begin{array}{l}\text { Menyusun narasi yang sesuai } \\
\text { dengan representasi yang } \\
\text { ditampilkan } \\
-\end{array} \text { - Menyelesaikan masalah } \\
\text { menggunakan kata-kata atau } \\
\text { secara tertulis }\end{array}$ \\
\hline
\end{tabular}

Hasil penelitian TIMSS terkait kemampuan representasi matematis siswa kelas VIII di Indonesia dalam mengenal ekspresi aljabar yang berhubungan dengan situasi sederhana masih rendah (Rahmawati, 2015). Rendahnya kemampuan representasi matematis siswa menuntut adanya perbaikan di berbagai lini. Kompetensi inti kurikulum 2013 di MTs/SMP pada Permendikbud No. 68 tahun 2013 tentang kurikulum MTs/SMP," n.d. menyebut bahwa dalam ranah konkrit siswa harus mampu menalar, mengolah dan menyaji (menggunakan, mengurai, membuat, merangkai, memodifikasi), sedangkan dalam ranah abstrak siswa dituntut menulis, membaca, menghitung, menggambar dan mengarang sesuai dengan teorinya. Artinya kemampuan representasi penting dimunculkan saat proses pembelajaran untuk membantu pemahaman mengingat siswa baru memasuki tahap operasional formal (berpikir dengan cara lebih abstrak, logis dan lebih idealistis).

Pentingnya kemampuan representasi matematis diungkapkan Abdullah (2012) sebagai komponen yang perlu mendapat perhatian khusus karena kemampuan ini selalu ada ketika siswa belajar matematika di setiap jenjang pendidikan. Hal ini terlihat dari standar representasi yang dikemukan NCTM Effendi (2012) untuk siswa taman kanak-kanak sampai tingkat SMA, yaitu penciptaan dan pemakaian representasi dalam mengorganisasikan, mencatat dan menyampaikan gagasan matematika; menentukan, menggunakan, dan menafsikan representasi dalam penyelesaian masalah; serta pemanfaatan representasi untuk memodelkan dan menerjemahkan gejala fisik, sosial dan matematis. Kemudian Fauzan (2013) juga mengatakan bahwa representasi menjadi landasan bagi siswa dalam memahami dan menggunakan konsepkonsep matematika. Derajat pemahaman dan 
penyelesaian masalah siswa dalam mengerjakan tugas-tugas matematika dapat dilihat dari kemampuan representasi matematisnya. Suatu soal yang sukar dan sulit akan menjadi gampang jika representasi yang digunakan cocok dan tepat dengan permasalahan yang ada. Sebaliknya, akan merumit jika representasi yang dipakai salah. Pemanfaatan model matematikan yang tepat dalam bentuk representasi membantu pemahaman siswa dan mengungkapkan ide matematikanya.

Kepentingan ini tidak dipandang perlu oleh guru di sekolah. Fakta di lapangan menunjukkan bahwa kebanyakan guru belum memandang kemampuan representasi matematis sebagai suatu landasan penting dalam pembelajaran matematika. Hal ini sejalan dengan pendapat Hudiono dalam Rahmawati (2015) bahwa menurut guru representasi matematis siswa berupa tabel, grafik dan gambar jarang dilihat kemajuannya karena hanya dipandang sebagai aksesori pembelajaran. Tak jarang proses pembelajaran langsung pada inti pelajaran tanpa diawali dengan kegiatan pendahuluan seperti pemberian motivasi dan apersepsi. Kegiatan pembelajaran lebih banyak didominasi guru, siswa jarang dikasih kesempatan untuk memunculkan representasinya sendiri yang berakibat pada kecenderungan siswa untuk mengikuti langkah guru dalam penyelesaian masalah. Akhirnya kemampuan representasi matematis siswa tidak berkembang.

Kemampuan representasi matematis siswa dapat diukur dengan soal pemecahan masalah, seperti yang diungkapkan Hartono dalam Amdasari (2016) bahwa soal pemecahan masalah adalah soal yang diawali dengan penyajian masalah atau situasi kontekstual, namun dalam penyelesaiannya tidak hanya memiliki satu jawaban dan soal pemecahan masalah erat kaitannya dengan simbol-simbol yang membuat siswa susah dalam mengkaitkan permasalahan matematika dengan realita kehidupan dan merepresentasikannya ke dalam model matematika. Berbicara mengenai soal pemecahan masalah Herawati (Herawati
(2012) mengungkapkan bahwa terdapat 4 karakteristik soal pemecahan masalah yaitu: minimal mempunyai dua cara jawab; minimal mempunyai dua pemecahan; membutuhkan akal, penalaran dan percobaan; serta cocok dengan kehidupan nyata dan minat siswa.

Berdasarkan wawancara peneliti dengan guru matematika kelas VIII.8 MTsN Batusangkar pada tanggal 5 November 2016, diperoleh informasi bahwa soal-soal latihan yang diberikan guru untuk materi fungsi merupakan soal-soal rutin bukan soal pemecahan masalah (soal non rutin). Pada dasarnya masalah yang diberikan guru sudah berorientasi pada pengukuran kemampuan representasi matematis akan tetapi belum maksimal karena belum semua karakteristiknya terpakai. Guru juga mengatakan bahwa sebagian siswa kurang mampu dalam memanipulasi data untuk menemukan rumus fungsi akan tetapi sebagian besar siswa sudah mampu membuat tabel, grafik, diagran panah, dan pasangan berurutan dari data yang ada. Dapat dikatakan bahwa soal-soal yang diberikan guru belum dapat menguji kemampuan representasi matematis siswa bentuk verbal. Untuk itu perlu dilakukan sebuah kajian untuk menganalisis kemampuan repesentasi matematis dalam menyelesaikan soal pemecahan masalah matematika dalam bentuk visual, verbal, dan simbolik.

\section{METODOLOGI PENELITIAN}

Penelitian ini menggunakan metode deskriptif, Peneliti bermaksud memaparkan dan menginterpretasikan keadaan objek sebenarnya (Sugiyono, 2007). Sesuai dengan pertimbangan guru matematika di sekolah (purposive sampling) terkait kemampuan representasi matematis siswa Kelas VIII diambillah siswa kelas VIII.8 MTsN Batusangkar sebagai subjek penelitian. Lebih lanjut guru menerangkan bahwa siswa Kelas VIII.8 telah tampak memiliki kemampuan representasi matematis dan juga memiliki kemampuan matematis yang heterogen, artinya kemampuan matematis siswa di kelas 
ini beragam yaitu memiliki kemampuan matematis tinggi, sedang dan rendah.

Peneliti menjadi instrumen utama dalam penelitian kualitatif yang didukung oleh pedoman wawancara, sedangkan instrumen untuk memperoleh data kuantitatif adalah soal. Tes uraian dibuat berdasarkan karakteristik soal pemecahan masalah matematika yang di dalamnya terdapat karakteristik soal untuk mengukur kemampuan representasi matematis. Penelitian ini dilakukan pada materi fungsi. Sebelum perangkat tes diujikan terlebih dahulu dilakukan validitasi oleh beberapa pakar, dilanjutkan dengan uji coba, kemudian analisis butir soal. Uji coba dilakukan pada kelas yang memiliki kemampuan hampir sama dengan subjek penelitian. Setelah pelaksanaan tes selesai dilanjutkan dengan pemberian skor (skoring) sesuai dengan rubrik penskoran kemampuan representasi matematis. Kemudian hasil-hasil skor siswa disajikan dalam bentuk tabel agar lebih mudah dibaca untuk seterusnya dilakukan analisis. Analisis ini bermuara pada penentuan predikat kemampuan representasi matematis siswa dalam menjawab soal-soal pemecahan masalah matematika.

Untuk memperkuat dan mendalami lagi data penelitian kuantitatif, maka digunakan instrumen pendukung yaitu pedoman umum wawancara. Setelah pedoman wawancara selesai dirancang terlebih dahulu dilakukan validasi. Data hasil wawancara dianalisis menggunakan Analysis Interactive model Miles \& Huberman (1992) dengan tahapan: 1) reduksi data, ialah menyimpulkan, menyisihkan hal-hal penting dan memfokuskan pada hal-hal pokok, 2) penyajian data kemampuan repesentasi matematis siswa dalam menyelesaikan soal pemecahan masalah, 3) membuat kesimpulan secara keseluruhan.

\section{HASIL DAN PEMBAHASAN}

Data hasil tes siswa dengan 3 buah soal yang berbentuk uraian dapat dilihat pada tabel di bawah ini:
Tabel 2

Hasil Tes Kemampuan Representasi Matematis Siswa Menyelesaikan Soal Pemecahan Masalah Matematika

\begin{tabular}{|l|c|}
\hline \multicolumn{1}{|c|}{ Ukuran } & Hasil tes \\
\hline Rata-rata & 25 \\
\hline Nilai Terendah & 16 \\
\hline Nilai Tertinggi & 35 \\
\hline Standar Deviasi & 5,8 \\
\hline \multicolumn{2}{|c|}{ Catatan: Skor ideal adalah 36 }
\end{tabular}

Dari 34 siswa yang mengikuti tes terdapat 13 atau $38 \%$ siswa memperoleh skor di atas rata-rata. Rata-rata kemampuan representasi matematis siswa berada pada kategori memuaskan $(69,77 \%)$ artinya kemampuan representasi matematis siswa dalam menyelesaikan soal pemecahan masalah matematika cukup baik, tetapi masih ada indikator kemampuan representasi matematis siswa yang dimiliki siswa belum tercapai secara maksimal sesuai dengan yang diharapkan.

Untuk mempermudah penganalisisan data, peneliti mengelompokkan hasil penelitian berdasarkan indikator-indikator kemampuan representasi matematis siswa. Persentase rata-rata representasi bentuk visual dan simbolik berturut-turut sebesar $79 \%$ dan $73 \%$. Hal ini menunjukkan bahwa kemampuan representasi visual dan simbolik siswa berada pada kategori memuaskan. Untuk representasi verbal persentasenya $66 \%$ dalam artian siswa secara umum mampu mengerjakan soal pemecahan masalah dengan predikat cukup memuaskan.

Hasil tes kemampuan representasi matematis dan wawancara menunjukkan bahwa siswa memiliki keunikan tersendiri dalam menyelesaikan masalah, artinya kemampuan siswa berbeda-beda dalam menemukan solusi dari suatu permasalahan. Sebagaimana diungkapkan Paulina Pannen dalam Desmita (2009) bahwa cara dan kompetensi seseorang dalam menghadapi persoalan adalah unik.

Kemampuan representasi matematis siswa bentuk visual menggambarkan bahwa secara umum siswa sudah bisa menyajikan masalah ke dalam bentuk tabel, grafik, diagram panah, pasangan berurutan dengan benar dan lengkap, namun hanya saja masih terdapat kesalahan kecil dalam perhitungan matematika untuk mendapatkan data 
sehingga mengakibatkan siswa salah dalam menyajikan masalah ke dalam bentuk grafik. Ini disebabkan karena siswa masih belum paham dengan permasalahan yang peneliti berikan dengan baik. Hasil penuturan siswa bahwa sebagian dari siswa cukup paham dengan permasalahan walaupun ada siswa yang kurang lengkap dalam menyajikan masalah atau data ke dalam bentuk tabel, grafik, diagram panah, pasangan berurutan. Hal yang bisa dilakukan guru untuk melatih siswa dalam memahami persoalan antara lain dengan mempertanyakan beberapa hal, seperti: bisakah kamu merepresentasikan masalah dalam bentuk gambar, atau memanfaatkan notasi yang sesuai? Bisakah kamu mengklasifikasikan data sesuai dengan keadaan yang ada? (G. Polya dalam Fauzan, n.d.)

Selanjutnya, siswa sudah mampu mengimplementasikan permasalahan yang diberikan ke dalam berbagai bentuk penyajian fungsi seperti tabel, grafik diagram panah, dan pasangan berurutan dengan cukup maksimal. Tingginya rata-rata nilai siswa untuk indikator ini mengindikasikan bahwa siswa cukup familiar dengan istilahistilah yang digunakan serta fenomena yang ada pada soal ini. Akibatnya, siswa mampu memberikan pemahaman pada soal melalui gambar untuk mempermudah mereka dalam menemukan pemecahan masalah yang tepat. Selanjutnya pendapat Ahmad Fauzan diperkuat oleh (Buhaerah, n.d.) mengatakan bahwa: salah satu hal yang bisa dilakukan dalam memformulasikan masalah ialah menyajikan masalah secara matematis dalam bentuk numerik, simbolik, verbal atau grafik.

Kemampuan representasi matematis siswa bentuk verbal bisa dilihat dari hasil wawancara terhadap beberapa orang siswa, untuk mengetahui sejauh mana pemahaman siswa terhadap jawaban yang telah diberikannya. Hasilnya menunjukkan bahwa hanya sebagian siswa yang mampu menginterpretasikan hasil perhitungan matematisnya secara logis dan sistematis. Soal ini lebih menekankan pada bagaimana siswa mengungkapkan interpretasi atau membuat kesimpulan dari hasil manipulasi data untuk memecahkan masalah matematika. Akan tetapi, sebagian siswa belum mampu membuat kesimpulan atas hasil manipulasi data untuk mencari solusi dari permasalahan yang diberikan dengan kata-kata secara lengkap di dalam lembar jawaban. Sebagian siswa sudah mampu menyimpulkan jawaban dari hasil manipulasi masalah melalui pemodelan matematika secara lengkap di lembar jawaban dan sebagian siswa lainnya mengalami kesulitan dalam membuat kesimpulan melalui katakata setelah melakukan perhitungan matematis. Setelah ditelusuri melalui wawancara, siswa mampu menjelaskan jawaban yang dibuatnya di lembar jawaban secara lengkap dan menyeluruh terkait solusi dan pertanyaan yang peneliti berikan melalui argumentasi yang diberikannya dan dapat menyimpulkan jawaban yang diberikannya.

Kemampuan representasi matematis siswa bentuk simbolik secara umum menunjukkan bahwa siswa sudah terampil membuat persamaan, model matematika atau representasi dari representasi lain yang diketahui, memecahkan masalah dengan menggunakan ekspresi matematika. Soal yang digunakan untuk mengukur indikator ini berkaitan dengan situasi kehidupan nyata siswa. Namun, masih banyak siswa yang kurang teliti dan ceroboh dalam menemukan solusi permasalahan sehingga siswa yang salah dalam hasil akhirnya. Hal ini diperkuat oleh hasil penelitian Hijriani, Rahardjo, \& Rahardi, (2018) pada siswa SMP dalam mengerjakan soal PISA menyimpulkan bahwa kekurang telitian siswa menjadi penyebab tidak mampunya siswa mengkonstruksi simbolik dan visual secara benar.

Setelah dilaksanakan penelitian, siswa dapat menyelesaikan masalah dengan baik melalui dugaan-dugaan dan manipulasi yang dilakukannya. Jadi dapat dilihat bahwa pada langkah merencanakan dan memilih strategi pemecahan masalah, kemampuan representasi khususnya untuk indikator representasi matematis bentuk simbolik sangat diperlukan. Karena tanpa membuat model dan manipulasi matematika secara 
tepat siswa tidak akan mampu memecahkan permasalahan. Sesuai dengan kata Anderson dalam (Fauzan, n.d.) bahwa serangkaian aktivitas kognitif digunakan untuk pemecahan dari suatu permasalahan. Aktivitas kognitif terkait dengan mengetahui permasalahan dan situasi mental serta melakukan manipulasi secara kontinu untuk mencoba teknik atau cara penyelesaian masalah.

Berdasarkan hasil kerja siswa dan melalui wawancara, siswa juga memanipulasi matematika melalui data-data yang terdapat pada tabel, grafik, diagram panah, dan pasangan berurutan. Hal ini dilakukan siswa agar mempermudah siswa dalam menyelesaikan masalah khususnya dalam menemukan apa yang hendak diselesaikan di dalam persoalan. Selain itu, melalui data pada tabel, grafik, diagram panah, dan pasangan berurutan tersebut dibuat dalam menyelesaikan persoalan agar siswa dapat menjemput kembali pengetahuan atau konsep apa saja yang akan digunakan untuk memecahkan masalah.

Fauzan, n.d. mengungkapkan bahwa terdapat berbagai cara penyelesaian masalah antara lain mereplikasi permasalahan (acting out the problem), menggambar atau membuat diagram, mencari pola, membuat tabel, membuatkan semua kemungkinan secara matematis. Ini menunjukkan bahwa salah satu strategi penyelesaian masalah dapat dilakukan dengan menyajikan permasalahan tersebut dalam bentuk tabel, grafik, gambar dan lain-lain. Strategi ini menuntun siswa mampu mendaftarkan semua informasi yang terdapat dalam permasalahan sehingga terlihat hubungan yang jelas antar bagian-bagian dalam permasalahan.

\section{KESIMPULAN}

Secara umum siswa sudah mampu menggunakan kemampuan representasi dalam menyelesaikan soal pemecahan masalah matematika. Akan tetapi, masih ada siswa yang belum lengkap dalam menyajikannya di dalam lembar jawabannya. Secara umum terkait kemampuan representasi matematis bentuk visual siswa sudah mampu menyajikan permasalahan matematika dalam bentuk tabel, grafik, diagram panah, dan pasangan berurutan dengan prediket memuaskan. Sedangkan dalam bentuk verbal, secara umum siswa sudah mampu menuliskan langkah-langkah pemecahan masalah matematis dengan katakata, menuliskan interpretasi dari suatu representasi, serta menjawab soal secara tertulis dikategori cukup memuaskan. Secara simbolik siswa sudah bisa membuat persamaan atau bentuk matematika dan memecahkan masalah dengan menggunakan ungkapan matematis yang mencapai predikat memuaskan. Akan tetapi siswa masih kurang teliti dalam mengerjakannya sehingga terdapat kekeliruan pada hasil akhirnya.

\section{REFERENSI}

Amdasari, W. (2016). Analisis Kemampuan Pemahaman Konsep Matematis dalam Menyelesaikan Soal Pemecahan Masalah pada Materi Persamaan dan Pertidaksamaan kelas X SMKN 1 Batusangkar. Skripsi: STAIN Batusangkar.

Aryanti, D., Zubaidah, \& Nursangaji, A. (2013). Kemampuan Representasi Matematis Menurut Tingkat Kemampuan Siswa pada Materi Segi Empat di SMP. Jurnal Pendidikan Dan Pembelajaran, 2(1).

Buhaerah. (n.d.). Jurnal Pembelajaran Berbasis Masalah untuk Meningkatkan Kemampuan Penalaran Matematis Siswa SMP. Pare-Pare: STAIN ParePare.

Dahlan, J. A., \& Juandi, D. (2011). Analisis Representasi Matematik Siswa Sekolah Dasar dalam Penyelesaian Masalah Matematika Kontekstual. Jurnal Pengajaran MIPA, 16(1).

Desmita. (2009). Psikologi Perkembangan Peserta Didik. Bandung: PT Remaja Rosdakarya.

Effendi, L. . (2012). Pembelajaran Matematika dengan Penemuan 
Terbimbing untuk Meningkatkan Kemampuan Representasi dan Pemecahan Masalah Matematis Siswa SMP. Jurnal Penelitian Pendidikan, 13(2).

Fauzan, A. (n.d.). Evaluasi Pembelajaran Matematika Modus Pascasarjana. UNP: Padang.

Fauzan, A. (2013). Keefektifan Pembelajaran MEAs dengan Mengintegrasikan NKB terhadap Kemampuan Representasi Matematis dan Self-Efficacy pada Siswa Kelas X. Skripsi. Semarang: Universitas Negeri Semarang Tidak Dipublikasikan.

Herawati, S. (2012). Desain Pembelajaran (Kajian Teritis dan Praktis). Batusangkar: STAIN Batusangkar Press.

Hijriani, L., Rahardjo, S., \& Rahardi, R. (2018). Deskripsi Representasi Matematis Siswa SMP dalam Menyelesaikan Soal PISA. Jurnal Pendidikan: Teori, Penelitian, Dan
Pengembangan, 3(5), 603-607.

Kartini. (2009). Peranan Representasi dalam Pembelajaran Matematika. Prosiding Seminar Nasional Matematika Dan Pendidikan Jurusan Pendidikan Matematika FMIPA UNY.

Miles, M., \& Huberman, A. M. (1992). Analisis Data Kualitatif: Buku Sumber Tentang Metode-Metode Baru. Jakarta: UI Press.

Permendikbud No. 68 tahun 2013 tentang kurikulum MTs/SMP. (n.d.).

Rahmawati, P. S. (2015). Pengaruh Pendekatan Problem Solving terhadap Kemampuan Representasi Siswa. Skripsi. Jakarta: UIN Syarif Hidayatullah Jakarta Unpublish.

Sabirin, M. (2014). Representasi dalam Pembelajaran Matematika. Jurnal Pendidikan Matematika UIN Antasari, 1(2), 33-44.

Sugiyono. (2007). Metode Penelitian Pendidikan. Bandung: Alfabeta.

\section{Article Metadata:}

Huda, U. Musdi, E. Nari, N. (2019). An Analysis of Students' Mathematical Representation Ability in Solving Mathematical Problems. Ta'dib, 22 (1), 19-26. http://dx.doi.org/10.31958/jt.v22i1.1226

Keywords: Analysis, Mathematical representation ability, Mathematical problem solving questions

Coresponding author: Ummul Huda, IAIN Batusangkar, ummulhuda@iainbatusangkar.ac.id 